International Journal of Biology, Pharmacy and Allied Sciences (IJBPAS) 'A Bridge Betusen caboratory and QRendo'

www.ijbpas.com

\title{
UNDERSTANDING THE CONCEPT OF KARMAJA VYADHI
}

\section{MANJULA K ${ }^{1}$, ARUN R VAIDYA ${ }^{2 *}$ AND ASOKAN $\mathbf{V}^{3}$}

1: Associate Professor, Department of Ayurveda Samhita \& Siddhanta, Parul Institute of Ayurved \& Research and Ph.D. Scholar, Parul Institute of Ayurved, Faculty of Ayurveda, Parul University, Vadodara, Gujarat, India

2: Professor, Department of Ayurveda Samhita \& Siddhanta, Parul Institute of Ayurved, Faculty of Ayurveda, Parul University, Vadodara, Gujarat, India

3: Professor, Department of Prasuti Tantra and Stri Roga, Parul Institute of Ayurved, Faculty of Ayurveda, Parul University, Vadodara, Gujarat, India *Corresponding Author: Dr. Arun R Vaidya: $\underline{\text { arun.vaidya@paruluniversity.ac.in }}$ Received 12 ${ }^{\text {th }}$ Dec. 2021; Revised $14^{\text {th }}$ Jan. 2022; Accepted $7^{\text {th }}$ Feb. 2022; Available online $5^{\text {th }}$ March. 2022 https://doi.org/10.31032/IJBPAS/2022/11.3.1024

\section{ABSTRACT}

Ayurveda aims at longevity of life with health through preservation and therapeutic aspect of natural healing of body and mind. Asatmyendriyartha samyoga, kaala and prajnaparadha are considered as the causative factor for vyadhi. Health and disease state of a person is influenced by the kala (season) as well as the deeds of the previous life. Karmaja vyadhi is the suffering due to the parinama of kaala related to the deeds of previous life or due to adharma. Daivavyapashraya chikitsa is the prime line of treatment. Epigenetics is a branch of science which deals with the reversible changes in genes which can be brought through changes in behaviours and environment. Current review article aims at understanding the concepts of Karmaja Vyadhi and its treatment.

\section{Keywords: Adharma, Ayurveda, epigenetics, Kaala, Karmaja Vyadhi} \section{INTRODUCTION}

The intimate relationship between the human body and the universe forms a major topic of the most holistic system of health care, Ayurveda. It establishes the inter-relation of somatic and psychic factors for the maintenance of health as well as for onset of diseases. The concept of diseases, its origin, causative factors are 
also attributed to unknown factors with the term "daiva". An exclusive description of daivavyapashraya ${ }^{2}, \quad$ karmaja vyadhi chikitsa $^{3}$, and promotive health care is found throughout the Samhita.

Aim and Objective: To review the concept of Karmaja Vyadhi

Materials and Methods: Review from Ayurveda Samhita and e- sources

\section{REVIEW OF LITERATURE:}

Vyadhi adhishtana is considered as sharira and manas ${ }^{4}$. The causative factors (hetu) of any disease is considered as adharma $^{5}$ and also categorized mainly as asatmyendriyartha samyoga, prajnaparadha and parinama ${ }^{6}$. These factors lead to the manifestation of karmaja, doshaja and sahaja vyadhi ${ }^{7}$.

\section{Karmaja Vyadhi:}

The deeds of past life are depicted as daiva. The bad deeds (papa karma) are attributed as the causative factors for the onset of disease. Such diseases can be cured only by the karmakshaya i.e, suffering the bad deed of past life ${ }^{8}$ and adoption of strict regimens. The disease which doesn't go in tune with hetu and lakshana as said by aptas, and is not cured with the general line of treatment can be considered as karmaja vyadhi; which will subside by the subsidence of karma phala ${ }^{9}$. They are classified into sadhya and asadhya vyadhi. ${ }^{10}$. Karmaphala is also one attribute for conception ${ }^{11}$ by its influence on atma and mana ${ }^{12}$. It is the causative factor for garbha vikruti and beejadushti ${ }^{13}$.

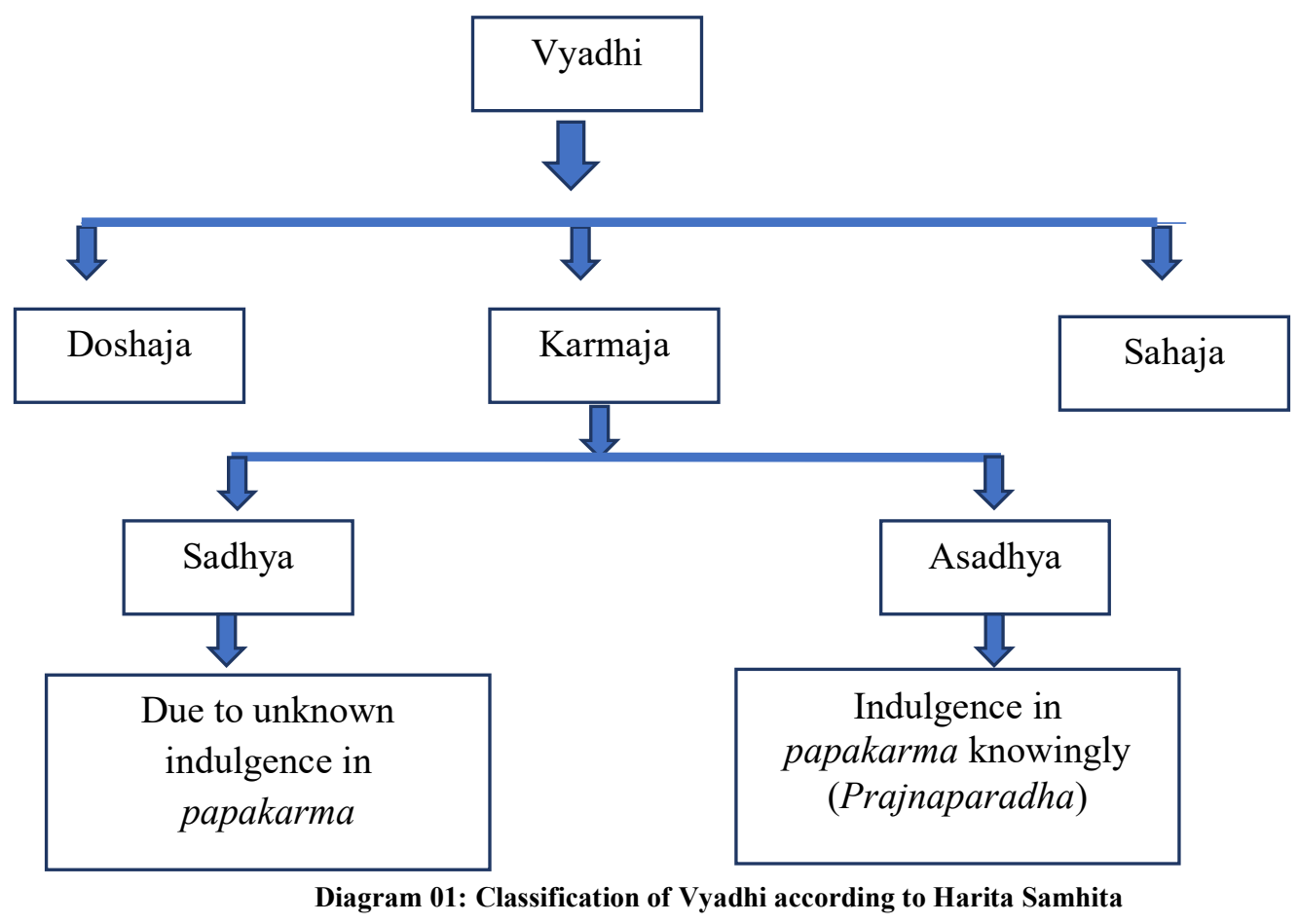


Dasha vidha Papakarma is enlisted in Ashtanga Hridaya. The papa karma enlisted in Harita samhita Papadosha Pratikara Adhyaya are brahmaghna (harming or killing brahmana), goghna (Killing Cow); dharanipati ghaataka (kills the king); aarama toyadhara nashaka (destroying the water reservoirs); paradaragamana (sexual intercourse with partners of others) like swamyangana (owners wife), gurupatni (teachers wife), kula vadhu (female of same lineage); the person who is stingy; who does impurity of sacred places; who does not give food to others; administration of poison; dhurta, bhruna pataka (foeticide); who sets fire in the forest; destroying the trees; stealing money, gold, silver, copper etc. valuable things; stealing ghee, oil; finding faults in others; and speaking harsh words. These lead to the following thirteen diseases which are pandu, kushta, rajayakshma, atisara, meha, mutraroga, ashmari, mutrakruchra, shula, shvasa, kasa, shopha, vrana. Further jvara, ajirna, chardi, bhrama, moha, agnimandya, yakrut-pliha vikara, arshas, shosha are considered as upadushaka ${ }^{14}$.

Karmaja hetu can be found in the manifestion of kushta, shvitra, udara, unmada as "Papam Karmam cha kurvatam”, “Guru Gharshana”, "Go Brahmana Ninda" in bruhattrayi. Karmaja vyadhi will be cured only after the complete regression of the karmaphala. Daivavyapashraya chikitsa plays a pivotal role in overcoming these diseases.

\section{Certain Illustrations for Daiva}

Vyapashraya Chikitsa in Samhita are as

follows:

Snana (maintaining personal hygiene), dana (Offering to the needy), japa, sura archana vidhi like homa (Sacred Rituals); bali (sacred offering), dana of gobhumi- kanaka - pana ${ }^{15}$, offering $1 / 16^{\text {th }}$ part of once own wealth is mentioned as one of the treatments in all the diseases ${ }^{16}$. Certain examples are

Table 01: Examples for daiva vyapashraya chikitsa

\begin{tabular}{|c|c|c|c|}
\hline Sl. & Vyadhi & Daiva vpashraya chikitsa & Refrence \\
\hline \multicolumn{4}{|c|}{ Mantra chikitsa } \\
\hline 1. & Vishama jvara & $\begin{array}{c}\text { Vishnusahasra naama Patana } \\
\text { Vanara puja, maayuri } \\
\text { Mahamayuri Vidya }\end{array}$ & $\begin{array}{c}\text { Charaka Samhita } \\
\text { Harita Samhita } \\
\text { Ashtanga Hridaya }\end{array}$ \\
\hline 2. & Arishta lakshana & Tripada gayatri & Sushruta Samhita \\
\hline 3. & Vishopakrama & Mantra chikitsa & Bruhattrayi \\
\hline 4. & Matangi vidya & Balagraha & Kashyapa Samhita \\
\hline 5. & $\begin{array}{c}\text { Agantu unmada } \& \\
\text { Apasmara }\end{array}$ & Rudra \& rudragana Puja & Charaka Samhita \\
\hline \multicolumn{4}{|c|}{ Aushadha \& Mani dharana } \\
\hline 6. & Bhuta jvara & Surasamula dharana & Harita Samhita \\
\hline 7. & Tritiyaka jvara & Apamargamula/nilinimula dharana & Harita Samhita \\
\hline \multicolumn{4}{|c|}{ Mangala } \\
\hline 8. & Sutikagara & Udakumbha sthapana, Akshata & \\
\hline \multicolumn{4}{|c|}{ Bali } \\
\hline 9. & Anti Natal Care & Homa, ishti yajna & Bruhattrayi \\
\hline
\end{tabular}




\begin{tabular}{|r|c|c|c|}
\hline \multicolumn{4}{|c|}{ Upahara } \\
\hline 10. & Balagraha & Dana & Harita Samhita \\
\hline \multicolumn{4}{|c|}{ Prayaschitta pranipaata gamanaadi } \\
\hline 11. & Karmaja Vyadhi & Chandrayanadi Vruta & Harita Samhita \\
\hline
\end{tabular}

\section{DISCUSSION:}

Kaala is given importance in Ayurveda. It can be svabhava i.e, ritu, vaya and avasthika ie, vyadhyavastha. Further upekshana is the line of treatment in initial phases of diseases to let the ama pachana and removal of vitiated doshas is also under influence of Kalaparinama. Similarly kaala plays an important role in karmaja vyadhi which are manifested due to papa karma. Jyotishya, prime among Vedanga deal with the time and unfolds the Karma and Karmaphala. Prayaschitta has to be done in the diseases which are not responding to the general line of treatment prescribed for the particular disease without which the person will suffer the disease in succeeding life also. Hence it is the only measure to prevent the disease and also to cure them.

The selection of these daivavyapashraya chikitsa like aushadha dharana (plants), their Sangraha kala (collecting seasons), Mani (gems), recitation of mantras, should be based on the nature of shareera (individual), sattva (mind), bala (strength) and assessment of Karma. They are effective on the body and are imbibed with the panchabhautika tattva of the universe including cosmic energy.
Hence the energies coming from the planets in this solar system always fall and are absorbed by the human body. Life force is indeed combined with these energies. When there is a deficit of any of these energies, the related problems will arise. The medicines of herbal or mineral origin, regulation of Prana through Pranayama, mantra chanting, use of pathya and apathya dravya according to seasonal variations can all contribute to eradication or pacification of even Karmaja vyadhi.

Epigenetics is the branch of science which study the affect of ones diet, exercise, behaviors and environment which cause reversible changes in the functions of genes. These changes begin even before birth, a pregnant woman's environment and behavior during pregnancy, such as whether she eats healthy food, can change the baby's epigenetics. It will occur throughout our life, it is not permanent changes which can be added or removed in response to changes in behavior or environment ${ }^{17}$.

Known causative agents behind epigenetic processes may include heavy metals, pesticides, tobacco smoke, polycyclic aromatic hydrocarbons, hormones, radioactivity, viruses, bacteria, 
and basic nutrients. These leads to manifestation of wide variety of illnesses including cancers, cognitive dysfunction, respiratory, cardiovascular, reproductive, autoimmune, and neurobehavioral illnesses ${ }^{18}$. Thus the effect of Daivavyapashraya chikitsa in treating Karmaja vyadhi can be justified.

CONCLUSION:

The whole world is now retrospectively analyzing the cause for the happenings in the current time. Not only dravyabhuta chikitsa is helping in the management of the diseases but also adravya chikitsa like mantra, mani dharana; for which the knowledge of astrology is essential. Thus daivavyapashraya chikitsa has a pivotal point in the diagnosis and treatment of karmaja vikara.

REFERENCE:

[1] Agnivesha, Charaka Samhita, Chakrapanidatta, Acharya Yadhavaji Trikamji, Chaukambha Sanskrit Samsthan, Fourth Edition s1994, Sha 2/44, pg 307, pp 738

[2] Agnivesha, Charaka Samhita, Chakrapanidatta, Acharya

Yadhavaji Trikamji, Chaukambha Sanskrit Samsthan, Fourth Edition 1994, Su 11/54, pg 77, pp 738

[3] Agnivesha, Charaka Samhita, Chakrapanidatta, Acharya
Yadhavaji Trikamji, Chaukambha Sanskrit Samsthan, Fourth Edition 1994, Sha 1/117,pg 298, pp 738

[4] Agnivesha, Charaka Samhita, Chakrapanidatta, Acharya Yadhavaji Trikamji, Chaukambha Sanskrit Samsthan, Fourth Edition 1994, Vi 3/20, pg 242, pp 738

[5] Agnivesha, Charaka Samhita, Chakrapanidatta, Acharya Yadhavaji Trikamji, Chaukambha Sanskrit Samsthan, Fourth Edition 1994, Sha 1/136, pg 299, pp 738

[6] Agnivesha, Charaka Samhita, Chakrapanidatta, Acharya Yadhavaji Trikamji, Chaukambha Sanskrit Samsthan, Fourth Edition 1994, Su $11 \mathrm{Su}$ 11/43, pg 76, pp 738

[7] Harita,Harita Samhita, Vaidya Jaymini Pandey, Chaukhambha Visvabharati, First Edition 2010, Trutiya Sthana 2/26, pg 195, pp544

[8] Agnivesha, Charaka Samhita, Chakrapanidatta, Acharya Yadhavaji Trikamji, Chaukambha Sanskrit Samsthan, Fourth Edition 1994, Sha 1/117,pg 298, pp 738

[9] K. Manjula et al (2021), Utility of Pramana in Ayurveda, Journal of Pharmaceutical Research International, 32 (42 B), 152-157 
[10] Harita, Harita Samhita, Vaidya Jaymini Pandey, Chaukhambha Visvabharati, First Edition 2010, Dvitiya Sthana 1/8-12, pg 138 139, pp 544

[11] Kashyapa, Kashyapa Samhita, Nepala Rajaguru Hemaraja Sharma, Chaukhambha Samskruta Samsthana, Ninth Edition 2004, Jatisutriya Adhyaya / $3, p g$ 79, pp 364

[12] Vagbhata, Ashtanga Hrudaya, Sarvangasundara Vyakhya \& Ayurveda Rasayana Tika, Pt. Hari Sadashiva Shastri Paradakara, Chaukambha Surabharati

Prakashan, Varanasi, Edition 2016, Sha 1/1, pg 361, pp 956

[13] Agnivesha, Charaka Samhita, Chakrapanidatta, Acharya Yadhavaji Trikamji, Chaukambha Sanskrit Samsthan, Fourth Edition 1994, Sha 2/29-30, pg 305, pp 738

[14] Harita, Harita Samhita, Vaidya Jaymini Pandey, Chaukhambha Visvabharati, First Edition 2010, Dvitiya Sthana 1/6-7, pg 138, pp 544

[15] Harita, Harita Samhita, Vaidya Jaymini Pandey, Chaukhambha Visvabharati, First Edition 2010, Trutiya Sthana 2/235, pg 226, pp 544
[16] Harita, Harita Samhita, Vaidya Jaymini Pandey, Chaukhambha Visvabharati, First Edition 2010, Dvitiya Sthana 1/21, pg 140, pp 544

[17] https://www.cdc.gov/genomics/dis ease/epigenetics.htm

[18] https://www.ncbi.nlm.nih.gov/pmc /articles/PMC1392256/pdf/ehp011 4-a00160.pdf 